\title{
(息)
}

Citation:

Ratna, A (2018) "Not just merely different: Travelling Theories, post-feminism and the racialized politics of women of color". Sociology of Sport Journal, 35 (3). ISSN 1543-2785 DOI: https://doi.org/10.1123/ssj.2017-0192

Link to Leeds Beckett Repository record:

https://eprints.leedsbeckett.ac.uk/id/eprint/4801/

Document Version:

Article (Accepted Version)

The aim of the Leeds Beckett Repository is to provide open access to our research, as required by funder policies and permitted by publishers and copyright law.

The Leeds Beckett repository holds a wide range of publications, each of which has been checked for copyright and the relevant embargo period has been applied by the Research Services team.

We operate on a standard take-down policy. If you are the author or publisher of an output and you would like it removed from the repository, please contact us and we will investigate on a case-by-case basis.

Each thesis in the repository has been cleared where necessary by the author for third party copyright. If you would like a thesis to be removed from the repository or believe there is an issue with copyright, please contact us on openaccess@leedsbeckett.ac.uk and we will investigate on a case-by-case basis. 


\section{Not just merely different: Travelling theories, post-feminism and the racialized politics of women of color}

\section{Introduction}

The historical legacies of women of color $^{1}$ activating against the machinations of mainstream sociology, de-constructing taken-for-granted theoretical developments across both critical studies of race and feminism, have already been the topic of scholarly inquiries. The work by Alexander and Mohanty (1997), Collins (2000), Gupta and Ferguson, (1992), hooks (1989), Kaplan and Grewal, I. (1994), Lorde (2007), Moraga and Anzaldúa (2015) and Spivak (1988) exemplifies the rich manifolds of these legacies. I am deeply moved by de-colonial feminist framings of knowledge production, and troubled by the general absence of these theorisations from discussions on sport, race and gender.

Having spent nearly two decades engaged in the sociology of sport, I have come to believe that critical knowledge in the field is hindered by a poststructural feminist analysis of difference. That is, the very theory that was imperative to moving beyond liberal notions of a global sisterhood in the first place. Let me be clear. What I am suggesting is not that poststructural feminist misunderstand the relationality of difference. But that the Whiteness

\footnotetext{
${ }^{1}$ Labels to classify different racial and ethnic groups is complex, encompassing local parlances, political symbolisms and forms of self-identification. Such terms cannot be easily used without considering the implications of how categories of difference are read and understood in the popular imagination, and by different groups in society. In my own research, I have often prioritised the label Black to signify a political identity which is inclusive of a range of racial and ethnic Others. However, in this paper, thinking about the American base of the Sociology of Sport journal, I have adopted the term "women of color" to speak meaningfully to different racial and ethnic groups including African American women. This is by no means ideal, and a term many American African women and others included within this labelling would choose not to use to represent themselves. But in terms of writing this paper, I favour this label as it is often used by transnational feminist authors who may speak about an array of women who share experiences of being oppressed and Othered, whilst recognising the politics of location (Mohanty, 2003).
} 
of Westernised framings of knowledge production, continues to reproduce homogenising and false narratives (Shih, 2002; see also McDonald and Shelby, 2018). In the process, obscuring coalescing sites of empowerment and resistance. The work does not, as Thangaraj (2015) argues, speak to other aspects of people of color's relationships to sport including bodily pleasures, desires, and affects. In the sociology of sport, there continues to be an urgent need to re-engage with feminisms that make visible systems of power, discourse and materialities (Birrell, 1989; Jamieson, 2003; Scraton, 2001; Smith, 1992).

Through this paper, I make a political case for why researching difference continues to politically matter as well as what it means to research with responsibility. Reflecting on the findings of a systematic review I undertook in 2015 (Author), I situate the problems and possibilities of researching sport and the engagements of women of color. From this analysis, I specifically question post-structural and post-feminist engagements with difference, how it has been appropriated and/or mis-appropriated. Two interconnected theoretical conjectures are further developed at this point: namely, representations of racialised and gender difference; and voicing the agencies of women of color. Finally, a transnational feminist framework is positioned, indicating the principles of such an approach to re-framing the concept of difference. I recognise that others engaged in and beyond the sociology of sport may wish to add to my analysis and/or to pursue different lines of enquiry. In the spirit of thinking collectively and critically, in the words of Douglas (2017: 573), my intention is to open-up a more "meaningful and liberatory sporting feminist project".

\section{Re-visiting the politics of difference}

The need to produce critical scholarship about women of color and their relationships to sport 
and physical activity has never been more urgent. In this increasingly globalised world, signs of social progress and individual choice do not and cannot remedy the "necropolitical ferocity" that discriminate "between those deemed disposable and those who are not" (Alexander, Kaur and Louis, 2012: 3). Difference does matter, and in this paper I do not suggest that it does not. But that a focus upon difference must not be at the loss of critically addressing the hierarchies that create divides, speaking back to different forms of racial and gendered violence. As exemplified by the 2017 International Women's March (following the presidential election of Donald Trump in America $)^{2}$, the g/local realities of women across different borders can coalesce, fashioning a conciliatory politics of resistance that unifies women because of their differences. While also being sensitive to their shared struggles against capitalist neo-patriarchal agendas.

The saliency of such social divisions are no more apparent than in the global realm of sport, which is frequently imagined and mobilised as a social-force-for-good. But which contains difference in order to reproduce the status quo through changing and new imperial encounters (Carrington, 2010; Darnell, 2010; Hayhurst, 2014; Jamieson, 2015; Oza, 2016). As scholars engaged in the sociology of sport, continuing to view sport as a political site is crucial. In the words of Alexander (2009: 474), we must question the "relationship between the mobilisation or performance of racialised and other forms of ethnicity and identity at the local, micro, and more ethnographic level" in order to consider the "unequal distributions of material and symbolic resources" whereby certain races and ethnicities are both overtly and covertly privileged over and above others. Lest we not forget, Grewal I. and Kaplan (1994: 17) warn that,

\footnotetext{
${ }^{2}$ During the writing of this paper, a second International Women's March took place in January, 2018.
} 
If feminist movements cannot understand the [racialised] dynamics of these material conditions, they will be unable to construct an effective opposition to current economic and cultural hegemonies that are taking new global forms (insertion added).

This challenge poses many questions, not least the hegemony of sport as a masculine preserve (Theberge 1987), reinstituted through the privileging of masculine tropes and theorisations, and the refusal to theorise more broadly.

In response to this challenge, I make a renewed call for listening to the writings and autobiographies of women of color (Birrell, 1989; Scraton, 2001). I am conscious that just because some of the terms of the debate, and indeed the scholarship of some women of color intellectuals - like Collins, hooks, Lorde, Mohanty and Spivak - are cited in studies of sport, we should not regard this as a fait accompli (Author). That is, the anti-racist feminist projects of such scholars has been achieved and thus does not require further engagement (Lu, 1997; Mane, 2012). In relation to this, Mane (2012) argues that black feminism is sometimes deemed dead, what else can it add which is not already known by most feminist scholars? I argue that just because some of the terms of the debate may be popularly recited e.g. like difference, does not mean that the utility of the term is over for thinking about future directions for feminism. I suggest that scholars - including myself - become epistemologically uncertain, querying slippages in conceptual meaning and application, and that new lessons may be gleaned from past, present and different uses of black feminist thinking as well as mash-ups of other theoretical positionings (e.g. Carter-Francique, 2017). 


\section{Researching with Responsibility ${ }^{3}$}

I am also reminded of Mirza's (1997) notion of hanging-out in the trendy spaces of the margin. Whereby the colonising of women of color epistemologies can advance careers in a neo-liberal academy. But can be completely divorced from on-going feminist, anti-racist and anti-imperialist activisms. I also question if the Whiteness of some scholars grants them agenda-setting powers, not always afforded to women of color (Author). I want to make another point though. To advocate for scholarly activisms that not only make room for different women of color to have claims to space, representation and intellectual powers, but that the responsibilities of White men and women scholars in relation to this process matters too. The positive reception and citation of Birrell and Scraton (both White women), for instance, is a testament to researching with responsibility. The impact of critical thinking as a progressive project to recovering knowledge about women of color and sport, which also endeavours to create spaces for mutual support and dialogue (see Author; McDonald, 2009; Mitra and Chawansky, 2018; Falcón, 2016; Vertinsky and Captain, 1998).

As a British Asian sport sociologist, I have undoubtedly benefitted in various ways from working across (a changing) Westernised academic context. It would be insincere to suggest I have not gained academic training, esteem and economic mobility from being in this profession (see also Falcón, 2016; Kim, 2012). I am conscious that in speaking for and about scholars from the Global South, my own Western (albeit diasporic) agenda-setting power is reproduced. It is not my intention to reinforce the imperialist and exploitative boundaries between who is seen as producers of knowledge (Global North/ Westerners) and who is seen as the (passive) consumers (Global South/ non-Westerners) (Alcoff, 1991; Falcón, 2016). I

\footnotetext{
${ }^{3}$ See Watson and Scraton (2001) and Watson and Scraton (2017)
} 
also want to move beyond a simplistic "West is the best" diktat. Relativistic thinking which compares scholars from the West/Global North (as superior) and non-West/ Global South (as inferior) can only consolidate false and problematic binaries. In line with the broader argument of this paper, I recognise that scholars from across these different geo-political locations are differentially impacted by White, Western, elitist, heterosexist, and patriarchal structures, and that this sociological history and context should not be ignored.

For many diasporic and racial Others in academia (like myself), in and across different Western and non-Western nations, we negotiate and hold complex and changing positions of power (hooks, 1989; see Author for further debate). In recognising my own privilege (and alterity) I do not retract from the responsibility of speaking to the lives of women similar and different to myself (Alcoff, 1991; see also Kim, 2012). The critical insights of Falcón (2016) in this respect have been particularly illuminating. It has made me question how I research with responsibility; re-considering how I approach the research process, what questions I ask, and how I work dialogically with the groups that I research for and about (Author). Importantly, it has also made me query the effect of my scholarship; how it may travel across different geo-political borders, including to the Global South, and how scholars from within those spaces will view it. I am also concerned about how the communities my research is for and about will receive the work. In respect of these concerns, I value Falcón's (2016: 189) notion of developing a 'political commitment to communities over institutions'. In respect of this, I am willing to listen, to learn, and to try harder to research with responsibility by inviting critical dialogue and exchange.

It would be remiss though not to recognise the prominence given to work written in the 
English language. This focus renders invisible non-English contributions from outside the Western metropolis (and indeed, scholarly contributions from outside of academia). This is not to suggest translations from English to other languages are not available, as they are in some sporting journals. But that the translation process can be problematic, ignoring complex cultural differences and subtleties in meaning, which can perpetuate problematic re/presentations (Falcón, 2016; Kim, 2013). I am also reminded of hooks' (1989) claim that the English language carries the scent of colonial and imperial oppressions. It may therefore be resisted as a vehicle to 'dismantling the Master's house' (Lorde, 1997) by scholars both inside and outside of a Western academic context (Author; Falcón, 2016). A choice to refuse representation and/or a desire not to be known (Collins, 2000). Rejecting in the process persisting White, Western, secular and universalising forms of knowledge production and control (Falcón, 2016). As I outline next, discourses of difference are so deeply entrenched in much of the literature about women of color and sport, that they become hard to escape from.

\section{Reviewing the "critical" in critical studies of race, gender and sport}

In 2015, I conducted a systematic literature review of research (articles and book chapters) about race, gender and sport, specifically in regards to the engagements of girls and women. Starting from the year 2000 - the year before Scraton (2001) made her call for further research in the area - to the end of 2015. I found a substantial body of work: 121 articles in $\operatorname{total}^{4}$ published in and for English-speaking nations. At first glance, this may be viewed as a

\footnotetext{
${ }^{4}$ It should also be noted, that this survey generally excluded research based on a university and school context as educational institutions between nation varies considerably, limiting meaningful comparison. The exception to this rule was research articles from a U.S. context, where collegiate sport is professionalised. Further still, the race and ethnicity of the authors cannot always be deciphered from a name in order to identify "who" is researching "who". Indeed, some authors did not mention their race and ethnicity as part of their research which makes it difficult to account for their representational responsibilities.
} 
positive development with a steady flow of articles being published globally; approximately eight publications a year over the last 15 years. This developing body of work though tends to focus on three main areas. First, almost a third of all the research was specifically about African American women (good examples include but are not limited to Adjepong, 2015; Armstrong, 2007; Bruening, 2004; Mowatt et al, 2013; Ross, 2009; Van Ingen, 2013; Withycombe, 2011). This perhaps reflects the dominance of the U.S. context more broadly in the sociology of sport. Research about indigenous communities and/or diasporic migrant groupings in America were relatively under-represented.

Second, research about South Asian and/or Muslim women (although representing highly differentiated communities, are sometimes treated as the same) collectively accounted for another third. This scholarship was geographically wide-spread, covering parts of America (e.g. Shankar, 2014), Australia (e.g. Palmer, 2009) Canada (e.g. Jiwani and Rail, 2010), England (e.g. Ahmad, 2011), India (Mitra, 2014) and the Middle-East (e.g. Erhart, 2013), for instance.

Third, clustered together, the sporting engagements of particular groups of women of color, across the Global North and South, was evident. For example, a few interesting studies focused on women from Africa (e.g. Leseth, 2014; Pelak, 2005), Asia (e.g. Ho, 2014), Australasia (e.g. e.g. Macdonald, Abbott and Jenkins, 2012; Palmer and Masters, 2010) and South America (e.g Filho and Rubio, 2012). However, despite the expansive terrain of the Global South, very little is known about the lives, differences and sporting engagements of women from across these geographic locations and/or in terms of their transnational movements (exceptions include Kedhar, 2014; Kim, 2012; Joseph, 2014; Sykes, 2016; Yep, 
2010, 2012).

Although I cannot reflect on the problems and possibilities of all the literature unearthed as part of this review process here (for futher debate see Author), what I found to be particularly frustrating was that many so-called "critical" studies continued to reify and drive particular narratives. Structural or cultural critiques of sport were mostly rendered invisible, not worthy of further interrogation or debate. For me, this kind of scholarship is most painfully driven home on work that engages with research about women and girls of the South Asian diaspora. On the one hand I acknowledge writings that account for the dynamic realities, multiplicities and complexities of South Asian girls and women as sports participants, fans and consumers (e.g. Author; Kedhar, 2014; Toffoletti and Parmar, 2015; Samie, 2013; Shankar, 2013). On the other hand, I remain frustrated by uncritical and singular claims about "them" - as an undifferentiated whole - being caught in-between conflicting cultures. Meaning, restrained by the prevalence of culturally coded notions of acceptable femininity, prioritising family commitments, domestic chores, archaic notions of "honour" and academic achievements, ahead of sports and their own divergent needs and interests (for further debate see Author; Raval, 1989; Samie, 2017; Toffoletti and Palmer, 2015).

Thinking more broadly about the possibilities of social transformation, and the role of academic activisms, I am left wondering, for instance, about the impacts of (problematic) state multicultural policies, Islamophobia, racisms, and the governance of sport as a White neo-patriarchal occupation. I am also interested in the pleasurable possibilities of racialized bodies moving in and through space, co-ethnic, gendered and sexual desires. It is also important to not lose sight of the solidarities which might emerge from connecting with an 
array of other social groups. The framing of theoretical knowledge, in and across the field, arguably needs to be further unpacked in order to identify how knowledge about women of color and sport can be critically progressed.

\section{Difference and Critiquing Post-Feminism}

This task requires returning to the vicissitudes of postmodernity and poststructuralism, and how this has been taken-up through a White, Western, Eurocentric, secular and universalising feminist lens. One of the key questions remains, how do we account for cultural pluralism and equity without falling into a relativist trap of positioning some women as modern/ progressive and others as pre-modern and backward? Grewal I. and Kaplan (1994), amongst others, are not suggesting scholars dismiss postmodernism, and the notion of multiplicity and individuality. But that we remain committed to an anti-racist feminist agenda. As the African American Black feminist bell hooks (1990: 26) suggest "not to separate the "politics of difference' from the politics of racism".

Questions of difference significantly provided an important antidote to White feminism. Shattering the notion of a liberal and global sisterhood. Postcolonial scholars though argue that the erasure of race, colonialism and other forms of imperial control and power from feminist scholarship, has in the past reproduced a simplistic narrative of difference. That is, based on perceptions of 'us' (from the West/ Global North) and 'them' (from the non-West/

Global South). Arguably, fixing diasporic identities as well as spaces of the West/ Global North and non-West/ Global South in the process. 
Post-feminism, on the other hand, is particularly built on the assumption that the need for feminism is over, and cultural plurality can co-exist within women's liberalism. In Western societies such as the U.S., Gill (2008) goes further than this and claims that postfeminism as a sensibility recognises the affect of cultural representations and systems of exclusion. But that individuals can and do become empowered and self-actualising citizens. The "can-do" (Gill, 2008; Ringrose, 2007) attitude espoused in such post-feminist narratives ultimately exaggerates the freedom of girls and women. Down-playing White supremacist, elitist, heteronormative, ageist and able-bodied cultures dominant within Western (sports and) societies (Butler, 2013; McRobbie, 2009). But, blames marginalised girls and women themselves for choosing not to assert greater governance over their own bodily choices.

Though as Butler (2013) suggest, we must be careful not to elide how post-feminist discourses may be ambiguously mobilised by women of color, in different and complex ways, as a part of an individualised sub-conscious/ conscious strategy to assimilate and/or alter their everyday lived realities. Samie and Toffoletti (forthcoming) further highlight how the media representation of two African American Muslim sportswomen - Ibtihaj and Dalilah Muhammad - at the Rio 2016 Games were underscored by a post-feminist rhetoric. In different ways, the bodies of these two athletes were read as revealing their respective sensibilities as Muslim-American and free, rather than veiled and unfree; narrating a discourse about the possibilities of becoming a "good" (meaning: assimilated) Muslim female American subject.

Shifting the lens further to explore transnational power relations, Cole and Hribar (1995) argue that the post-feminist agenda operating in America, in regards to the Nike 'Just Do It' 
campaign, makes very little connection to "Third World" women as producers of sporting goods in an oppressive capitalist patriarchy (see also McDonald, 2000; Scraton, 2001). It also ignores "them" (whoever is lumped as non-Western) as workers in various sport and/or leisure industries "in" the West (Jamieson and Choi, 2017). Feminism, as a Western cultural phenomenon becomes an international commodity in-and-of itself, connected to various economic rationalities about 'saving' marginalised girls and women in the non-West. Usually implying from "their" governments, "their" religions and "their" men (for a critique and further debate see Chawansky and Hayhurst, 2015; Darnell, 2010; Darnell and Hayhurst, 2011; Hayhurst 2014, 2016; and Mohanty, 2013). Hayhurst (2014) adds, as part of this development work, social problems are often off-loaded onto the girls themselves. It is claimed that, through sport, these girls can develop enterprising skills which should not only boost their confidences but also address wider inequalities from within "their" ethnic communities and "their" countries.

This homogenising narrative of course ignores the heterogeneous positioning(s) of nonWestern girls and women as well as side steps the responsibility that governments and wider social and political agents have in challenging global capitalist patriarchies. What also escapes from critical questioning of international sport-for-development programmes, as debated by Nicholls, Giles, and Sethna (2010), is the failure of a post-feminist logic to problematize the colonisation of knowledge. That is, not only the lack of evidence pertaining to "real" impacts but also the scarcity of studies, literature and data from rather than about the Global South. The neo-liberal post-feminist position ultimately reproduces an image of the West/ Global North as superior and progressive through juxtapositionings of the non-West/ Global South as needing development, solidifying postcolonial hierarchical relationships. 
What is ultimately left across the vagaries of post-structural and post-feminist engagements with difference, is the functional philosophy of sport as an international-force-for-socialgood. Who makes up the West, and what is constituted by the values and meanings of social life in the West, are left unquestioned. To make sense of the tensions generated by poststructural and post-feminist accounts of difference, I further lament on two interconnected processes of knowledge production: namely, colonised re/presentations of racial and gendered difference; and uncovering subjugated knowledge, voice and agency.

\section{Colonial Re/Presentations}

What is central here, in the words of Gupta and Ferguson (1992), is the naturalisation of difference. For example, representations of African American sporting women's physicality as "naturally" powerful and muscular (see Mowatt et al., 2013; Vertinsky and Captain, 1998). The dominance of this racial trope has been most publically symbolised through the re/presentation of African American female tennis players, sisters Venus and Serena Williams, as overtly-muscular and unfeminine (Douglas, 2002; Ifekwunigwe, 2009; Spencer, 2004). The sisters' re/presentation it seems only works in this context to further bolster the image of elite, White, Western, heterosexy and able-bodied players. Arguably, we may never know "who" African American women are, whether as elite players or as recreational sports enthusiasts. Their complex, dynamic and multifarious engagements with sport and physical activity, and the experiential affect of contingent inclusions/ exclusions, are rendered invisible. It becomes only possible to know "them" in and through (problematic) dominant discourses (see Carter-Francique, 2017; Douglas, 2017). 
In her evocation "why can't the subaltern speak", post-colonial scholar Gayatri Chakravorty Spivak (1998) argues that the erasure of women of color from critical analysis involves understanding the slippage between the two meanings of representation: vertreten and darstellen. Spivak argues that vertreten is a political action by someone else, who appears to work in another's interest, in order to represent the stories, political consciousness and values important to the subaltern. Many sport scholars claim to do such a service, faithfully interpreting evidence from the field to improve access, equality and the inclusion of women of color. Linked to vertreten, darstellen on the other hand, is a form of re/presentation. Drawing a portrait of the subaltern which may be multiple, polymorphous and dynamic. Yet when this complexity is nevertheless reduced to limited and narrow physical and/or cultural tropes of difference, the "solutions" to facilitating positive engagement is not only misinformed, but also mis-names racial and culture difference (Lorde, 1997).

Spivak (1998) claims that the task of the intellectual is therefore to deconstruct and reconstruct history. To understand why some versions of social reality become the normative frame for understanding difference, whilst other versions slip from critical analysis. Arguably, we cannot know the emerging subjectivities of the subaltern as the centre requires an Other to make sense of itself (Grewal, I. and Kaplan, 1994). More than this, the hegemony of (male) Imperialist as Subjects of modernity, individuality and social progress can only be achieved by unequivocally marking a supposed difference (Bhambra, 2011). In order to move away from dominant (and false) re/presentations in the sports literature, scholars must pay careful attention to the silences (what is not said about the subaltern subjects' social realities), acts of insurgency (through ritual, bodily practices/ movement and actions as well as speech acts) and trace the historical and social itineraries of subaltern 
women as a method of recovering their multiple and differentiated locations of being (Author). That is, moving beyond colonial and imperial productions of difference.

Thangaraj (2010, 2015), for example, does this convincingly in his study about Indo-Pak male basketballers. These men appropriate "cool” Black masculinities and heterosexual poses in and through their dress, language, displays of tattoos, and choice of music, enabling them to embody an American South Asian-ness. Thangaraj (2010, 2015) though astutely notes what is left out from this racialized and gendered performativity. That is, how the performances of South Asian American basketballers sub-ordinates (South Asian American) women and queer subjects. Their voices and subjectivities are consequently erased, in differential ways, through this process. But by acknowledging and addressing the relationality and intersectionality of wider racial, ethnic and sexual power geometries, this knowledge can be used to facilitate social transformation for a variety of other Others.

\section{Voice, subjectivity and agency}

Grewal, K. (2012) sums up the positive potential of making audible the voice of racial Others. The voices and biographies of marginalised groups are favoured as a means to not only illustrates exclusionary practices. from the lived experiences of subaltern women, but importantly, to shift representational power. That is, from White (Western and secular) feminist to Othered subjects themselves. Fraser (1990) refers to this as a basis for creating a subaltern counter-public sphere. This task is problematic though as the desire to capture the identities and sporting experiences of different women of color can never be fully achieved; imaginings of the 'self' are not fixed and evolve across time and space (Grewal, I. and Kaplan, 1994). But further still, Western epistemologies, methodologies and language may never be able to capture the nuances, pleasures and affective possibilities of women of color's 
relationships to sport (Hayhurst, 2016; Kim, 2013).

I am also wary of this approach for another reason. In agreement with Gugelberger and Kearney (1991: 8) I question how representations of subaltern subjects are co-opted in a way that may be counter-productive. For instance, I find this most commonly associated to scholarship which whilst at times well-meaning, un/intentionally (over-)focuses upon issues relating to "culture" and "religion". As if cultural and religious affiliations can only belong to some groups of people. In the literature, this logic was usually evident in relation to research about Muslim sportswomen. I, like Samie (2017), find the lack of questioning broader structural, political and mediated representations short-sighted, ignorant of the ubiquity of powerful forces of social exclusion and alienation. What's more, the writer (who is often but not always White, Western and secular) speaks from a position of individuality whilst often conferring representation to a collectivised Other (for further debate see Grewal, K, 2012). Erasing, at the same time, the many sporting stories, desires and pleasures of women of color, who may see their lived experiences differently from homogenising representations. Thus, the writer absolves his/her responsibility, citing the words of the subaltern subject as "proof" of their subjectivities, as articulated by "them" in their own words (Grewal, K, 2012). What this standpoint does not and cannot say is the ways in which their (meaning: the writer and the subaltern subjects') realities may be connected across time and space (see below). Narayan (1997: 145) adds:

'The Authentic Insider' position becomes profoundly limiting for Third World individuals when they get routinely cast as Native Informants while being denied auditions for other roles they could play just as well.

Grewal, K. (2012: 587) adds, 
...she is not - and cannot be - seen as having a worthwhile perspective in and of herself" (original emphasis).

By only focusing upon resistance, agency is chiefly read as being expressed in opposition to something or somebody. It assumes that women of color act always in response and thus lack any originality, any formations outside of the occident, and fail to have their own intentions, desires, and pleasures.

I suggest that to "see" the lived realities of women of color, requires a focus upon agentic choices. These are not so easily translated into visible or audible forms of resistance. Agency can lurk beneath the skin and/or become enacted within/through the body. Samie's (2013) analysis of Muslim women basketball players, who represent the United Kingdom at the Muslim Women's World Games in Iran, engages with this kind of agency. By observing, interpreting and talking to different players, Samie focuses upon the different ways they gain pleasure from surveying their bodies as powerful, physical and heterosexy. Samie particularly argues that by reading the construction of Muslim women's bodies beneath and beyond religious constructions of the veil, alternative representations of their gendered and sexualised bodies become available to the researcher. As previously suggested, illustrating the conscious/ sub-conscious way women of color connect with post-feminist and Westernised constructions of hyper-femininity in order to make sense of their own embodiments. Samie though, importantly, re-constructs the embodied narratives of Muslim women in order to speak back to structures of exclusion that do more than just perpetuate false and 'extreme hyperboles' (Grewal, K. 2012: 576). Thus, Samie is able to attend to questions of multiplicity, contradiction and difference, whilst exposing historical manifestations of racism, Islamophobia, sexism, elitism, able-bodiedness and 
heteronormativity (see also Mane, 2013).

A poststructural feminist obsession with difference can become yet another form of colonisation. Perpetuating homogenizing narratives about women of color without questioning how these constructed knowledges become common-place and accepted ways of thinking. Listening to the critical insights of scholars such as Anzaldúa, hooks, Collins, Grewal, Moraga, Mohanty, Spivak and many more, I suggest that we must learn to move beyond other-self dialectics and speak to broader transnational flows of knowledge, power and culture, and to locate our analysis historically.

\section{Travelling Theories - Transnational Feminism}

The historical travels of feminism are important to consider, as they are by no means linear (Caudwell, 2009), and because White and Westernised forms of (secular) feminism have been resisted. Black women, lesbian women, working-class women, disabled women and women from non-Western nations have all troubled in different ways universalising notions of Woman. The challenges to White feminism during the women's movement in America, for example, was crucial to the formation of both post-structural feminism and Black feminism. Therefore, how feminism has moved as a theory, and been mobilised in different ways across different sites, and for different reasons, brings to the fore how men and women are differentially impacted by intersecting relations of power and control. Transnational feminism brings together the expansive insights of different women of color theorisings (even if the scholar appropriated may not necessarily identify as such, see Herr, 2014). 
As a central concern, transnational feminism seeks to disrupt scholarly enquiries which focus upon the places which "root" people - where they are "originally" from - as a basis for understanding difference (Gupta and Ferguson, 1992: 20). The insights of Chicana feminist are important here as they have added much to this debate (e.g. Moraga and Anzaldúa) especially in regards to their notion of thinking in/ through/ across borders and the borderlands as well as mapping imperialist encounters between colonising outsiders and indigenous insiders. Relationships which have known to violently destroy and render meaningless rights to other ways of (spiritually) existing in and between humans and the environment. As territories symbolically represent class, gender, race, ethnic, age, sexual and able-bodied relations, they become the basis from which to critically examine the choices available to people at different locations within a defined field (Moraga and Anzaldúa, 2015; hooks, 1990) including those of sport.

Jamieson (2003), utilising Chicana feminist thinking, offers a middle-space approach to the sociology of sport. She signals the mestizaje consciousness that Latina elite softball women players embody and move between as raced, classed, gendered and sexualised subjects, immersed in a setting permeated by Whiteness. In this context, their sense of self does not easily fit into one category or another but coalesces, involving processes of alignment and resistance to spaces of power, in complex, shifting and differential ways. Jamieson, together with Choi (2017), in their analysis of the Mexican golfer Lorena Ocha, further illustrate how the racialized, classed, and gendered sites and spaces of U.S. golf, for example, can be moved through and resisted. In their cultural analysis, they particularly reveal how Ocha adopts various disidentifying manoeuvres towards a brown commons; a place of racial and ethnic solidarity, challenging the neo-liberal marketization of a (suitably) brown "can-do" global girl project in the process. 
Following from this type of analysis, I contend that thinking about different types of social, cultural, military and political encounters and intersections, could help us as sport scholars to understand how asymmetries of power are made, maintained and/or challenged (Strongman, 2014). Encouraging researchers to place the local in a global context of "travel" (or flows) of people, ideas, concepts and capital signified through structures of race, gender, sexuality, class and so on. Spivak (1985) refers to this as encompassing both the static and porous nature of thinking through and across the boundaries of race, difference and nation. She further emphasises the need for a historical sociology (see also Bhambra, 2011). By critically retrieving past knowledge, to understanding how glocal hierarchies of power are (re)produced and thus, how they can be contested.

Spivak (1985) further argues that flows, cultural translations and syncretisms across various geopolitical sites, does not necessarily obscure the political significance of nation-states. Herr (2014) adds, in her analysis of the cross-overs and differences between transnational feminism and "third-world" feminism, that state policies and institutional mandates explicitly and implicitly position racialised bodies as inside and/or outside the imaginaries of the nation. Thus, the way global politics become modulated in/through the nation-state re-articulates citizenship rights and national belonging, and that this precarious position is often mobilised through highly gendered tropes about women's physical bodies (e.g. see Author, Joseph, 2014; Thangaraj et al, 2016; Yep, 2010, 2012).

In my own research about British Asian female football players, historical and colonial connotations of "their" passivity and physical frailty are often cited as justifications for their lack of engagement in sports such as women's soccer. Yet, by understanding the flow of 
Westernised constructions of compulsory heterosexuality, some of the participants in my study used this knowledge to re/position themselves closer to the dominant norms of the spaces of women's soccer in England (Author). That is, by embodying a heterosexual pose. Moreover, as a fan of the game, showing an understanding of the historical nature of racialized and secular divisions in the U.K., and beyond, one of the elite middle-class players ingratiated herself to fellow (male, White) England fans, at a world cup soccer match in France in 2003. She did this by being a bit laddish - drinking alcohol, engaging in banter, and singing populist football songs - enabling her to assimilate into the predominantly White, European, and male space of spectatorship. Reproducing this masculine and laddish culture in the process. Interestingly, her contingent inclusion in the postcolonial context of France, in 2003, is based on the exclusion of men who are either read as being white Irish Republican Army sympathisers (i.e. older enemies of the English nation) or Muslim male terrorist (a newer global threat across nations). Echoing Kaplan (1994), I suggest that this interpretation becomes possible by situating her story in regards to relational and interconnected histories and oppressions. This analysis also illustrates the links between different racialized groups of men and women, as well as divides, in and across different locations, altogether and at once. The chicana feminist scholar Maria Lugones calls this type of transnational theorizing a form of "world travelling" (1990: 390).

Intersecting and relational sociology, as adopted by transnational feminists such as Grewal, I. and Kaplan (1994), Mohanty (2003), Shohat (1992) and more recently Bhambra (2011), and Bhambra and de Sousa Santos (2017), rest on recognising links between disparate groups of men and women, and their lived choices, whilst 'worlding' their particular locations of being, and the connected systems of power which produce and maintain such unequal positionings (Spivak, 1985). For researchers, including myself, encounters with difference not only 
requires a critical unmasking of the connectivities between "us" (as researchers, participants, subjects, objects, writers, readers) but also a deconstruction of those links in order to expose historical and complex asymmetries of power.

Sykes' (2014) work is a good example of this. In her study about researching the sporting engagements of Palestinian girls, as a British-born Canadian scholar, she reflexively deconstructs the history of her surname. She makes her private self, public. The resulting scholarship provides a historical re-reading of imperial, neo-patriarchal, capitalist, gendered and sexualised contours of nation(s). Crucially exemplifying the conditions from which powerful hierarchies of exclusion link different women across national boundaries, identities, time and space. Significantly though, this reflexive and autobiographical work makes possible coalescing sites of both knowledge production and transformatory practice. In a similar vein, the reflexivity evident in Mitra and Chawansky's (2018) chapter, which chronicles their personal histories and engagements in sport, also marks how differences and links between co-collaborators as well as research participants can 'pave the way for fresher knowledge' by making the private-self public (page 202). I value such scholarship for recognising how complex and lived differences are made and challenged rather than just speaking to the experience of racial and ethnic difference (Kivel et al, 2009).

\section{Concluding comments}

Often, many scholars of sport became embroiled in a quest for representation, but which only serves to re- 'Other' those who are already 'Othered'. I argue that when well-meaning attempts to engage with difference obscures the lived realities of women of color, false and highly problematic stereotypes become consolidated. As critical researchers, we must be 
sensitive to the construction of difference in order to find solutions to tackling deeply-rooted forms of complex g/localised oppressions. Without such an approach, differences are contained, and racial and gendered violences remain impervious to transformation across intersecting, and fluidly changing collectivised boundaries of being and belonging.

The challenge of moving beyond research that positions women of color as just being merely different, is to "see through" the mask and discursive production of difference. Transnational feminism offers one approach to this challenge. It facilitates thinking through the differential impacts of complex systems of power, experienced in, through and across organising structures such as gender, race, class, sexuality, age etc., responding to both internal and external politics of the 'nation'. This is by no means the only approach, and other sport sociologist may favour different theoretical lenses. But, I value the insights of women of color. Their writings and autobiographies do not only speak to difference as experience, which is important to describe, but they elucidate how cultural differences are produced and reinforced. That is, through "shared historical process that differentiates the world as it connects it" (Gupta and Ferguson, 1992: 16; see Bhambra, 2011; Brah, 1996).

I argue that this is significant to relationally exploring "a world always already interconnected", and how various systems, institutional policies and practices, become the "means through which the disempowered are kept that way" (Gupta and Ferguson, 1992: 17). The connections between women (and men) from different racial and ethnic backgrounds can be recovered in order to reveal "the material histories of their differences" but that "racism...has a vested interest in obscuring and devaluing the complex skills involved in this" (Lugones, 1990: 390). It is this challenge that scholars of sport must contend with to move 
beyond problematic notions of difference.

For researchers, including myself, encounters with difference not only requires a critical unmasking of the connectivities between "us" (as researchers, participants, subjects, objects, writers, readers) but also a deconstruction of those links in order to research with responsibility and to expose historical and complex asymmetries of power. In an era of Trump, Brexit, unabashed White Supremacy, everyday sexism, homophobia, transphobia and disability discrimination, the time for such research has never been more urgent.

\section{References}

Adjepong, A. (2015) “"We're, like, a cute rugby team”: How Whiteness and heterosexuality shape women's sense of belonging in rugby', International Review for the Sociology of Sport, DOI: $10.1177 / 1012690215584092$

Ahmad, A. (2011) 'British Muslim Female Experiences in Football: Islam, Identity and the Hijab' in D. Burdsey (Ed.) Race, Ethnicity and Football: Persisting Debates and Emergent Issues, New York; Oxon: Routledge: 101-116.

Alcoff, L. (1991) 'The Problem of Speaking for Others', Cultural Critique, 20: 5-32.

Alexander, C., Kaur, R., and Louis, B.S. (2012) 'Identities: new directions in uncertain times', Identities: Global Studies in Culture and Power, 19(1): 1-7.

Alexander, C. (2009) 'Stuart Hall and "race”', Cultural Studies, 23(4): 457-482.

Alexander, M. J. and Mohanty, C.T. (Eds.)(1997) Feminist Genealogies, Colonial Legacies, Democratic Futures, New York; London: Routledge. 
Armstrong, K. (2007) ‘The nature of Black women's leadership in community recreation sport: An illustration of Black Feminist thought', Women in Sport and Physical Activity Journal, 16(1): 3-15.

Bhambra, G.K. (2011) 'Cosmopolitanism and Postcolonial Critique’ in M. Rovisco and M. Nowicka (Eds.) The Ashgate Research Companion to Cosmopolitanism, Farnham: Ashgate: 313-328.

Bhambra, G.K. and de Sousa Santos, B. (2017) 'Global Challenges for Sociology', Sociology, 51(1): 3-10.

Birrell, S. (1989) 'Racial Relations Theories and Sport: Suggestions for a More Critical Analysis', Sociology of Sport Journal, 6: 212-227

Brah, A. (1996) Cartographies of Diaspora: Contesting Identities, London; New York: Routledge.

Brah, A., and Phoenix, A. (2004) 'Ain't I a Woman? Revisiting Intersectionality', Journal of International Women's Studies, 5 (3): 75-86

Bruening, J.E. (2005) 'Gender and Racial Analysis in Sport: Are all the women white and all the Blacks men?', Quest, 57: 330-349.

Butler, J. (2013) 'For White Girls Only? Postfeminism and the Politics of Inclusion', Feminist Formations, 25(1): 35-58.

Carrington, B. (2010) Race, Sport and Politics: The Sporting Black Diaspora, Los Angeles, London, New Delhi, Singapore, Washington D.C.; Sage.

Carter-Francique, A. (2017) 'Theoretical Considerations in the examination of African American girls and women in sport' in A. Ratna and S.F. Samie (Eds.) Race, Gender and Sport: The Politics of Ethnic 'Other' Girls and Women, London: Routledge: 63-84. 
Caudwell, J. (2011) 'Sport Feminism(s): Narratives of Linearity?', Journal of Sport and Social Issues, 35(2): 111-125.

Cole, C.L. and Hribar, A. (1995) 'Celebrity Feminism: Nike Style. Post-Fordism, Transcendence, and Consumer Power', Sociology of Sport Journal, 12: 347-369.

Collins, P.H. (2000) Black Feminist Thought: Knowledge, Consciousness and the Politics of Empowerment (Second Edition), New York and London: Routledge.

Chawansky, M., and Hayhurst, L.M.C. (2015) 'Girls, International Development and the Politics of Sport: An Introduction', Sport in Society, 18(8): 877-881.

Darnell, S.C. (2010) 'Sport, Race, and Bio-Politics: Encounters with Difference in "Sport for Development and Peace” Internships', Journal of Sport and Social Issues, 34(4): 396-417.

Darnell, S.C. and Hayhurst, L.M.C. (2011) 'Sport for decolonisation: exploring a new praxis of sport for development', Progress in Development Studies, 11(3): 183-96.

Douglas, D. (2017) 'Some of us are still brave: Sport and the Social Production of Blackness', in Louise Mansfield, Jayne Caudwell, Belinda Wheaton and Beccy Watson (Eds.) The Palgrave Handbook of Feminism and Sport, Leisure and Physical Education, London: Palgrave Macmillan: 571-588.

Douglas, D. (2002) 'To be young, gifted, black and female: A meditation on the cultural politics at play in representations of Venus and Serena Williams', Sociology of Sport Online - SOSOL, 5(2):1-16.

Erhart, I. (2013) 'Ladies of Besiktas: A dismantling of male hegemony at the Inönü Stadium', International Review for the Sociology of Sport, 48(1): 83-98.

Falcón, S. (2016) 'Transnational Feminism as a Paradigm for Decolonizing the Practice of Research: Identifying Feminist Principles and Methodology Criteria for U.S.-Based 
Scholars', Frontiers, 37(1): 174-194.

Filho, M.A.T. and Rubio, K. (2012) 'Between the Confrontation and the Concession: The Identities of Brazilian Olympic Female Athletes', International Journal of Humanities and Social Science, 2(20): 44-51.

Fraser, N. (1990) 'Rethinking the public sphere: a contribution to the critique of actually existing democracy', Social Text, 25(26): 56-80.

Gill, R. (2008) 'Culture and Subjectivity in Neoliberal and Postfeminist Times', Subjectivity, 25: 432-445.

Grewal, I., and Kaplan, C. (Eds) (1994) Scattered Hegemonies: Postmodernity and Transnational Feminist Practices, London; Minneapolis: University of Minnesota Press.

Grewal, K. (2012) 'Reclaiming the voice of the "Third World Woman", Interventions: International Journal of Postcolonial Studies, 14(4): 569-590.

Gugelberger, G., and Kearney, M. (1991) 'Voices for the voiceless: testimonial literature in Latin America, Latin American Perspective, 18(3): 3-14.

Gupta, A. and Ferguson, J. (1992) 'Beyond “culture”: Space, Identity and the Politics of Difference', Cultural Anthropology, 7(1): 6-23.

Hayhurst, L.M.C. (2016) 'Sport for Development and Peace: a call for transnational, multisited, postcolonial feminist research', Qualitative Research in Sport, Exercise and Health, 8(5): 424-443.

Hayhurst, L.M.C. (2014) “The Girl 'Effect' and martial arts: social entrepreneurship and sport, gender and development in Uganda", Gender, Place and Culture, 21(3): 297-315. Herr, R.S. (2014) 'Reclaiming Third World Feminism: or Why Transnational Feminism 
Needs Third World Feminism', Meridians: feminism, race and transnationalism, 12(1): 1-30.

Ho, M.S. (2014) 'Is Nadeshiko Japan “feminine”? Manufacturing Sport Celebrity and National Identity on Japanese Morning Television', Journal of Sport and Social Issues, 38(2): 164-183.

hooks, b. (1990) Yearning: Race, gender, and cultural politics, Boston, MA: South End Press.

hooks, b. (1989) Talking Back: thinking feminist, thinking black, Boston, MA: South End Press.

Ifekwunigwe, J.O. (2009) 'Venus and Serena are 'doing it' for themselves: Theorizing sporting celebrity, class and Black feminism for the Hip-Hop generation' in B. Carrington and I. McDonald (Eds.) Marxism, Cultural Studies and Sport, London and New York: Routledge: 130-153.

Jamieson, K.M. (2015) 'Making the Global Tour Turn: The USLPGA, Commissioner Rhetoric of Difference, and "New Imperialism"', Journal of Sport and Social Issues, 39(6): 501-520.

Jamieson, K.M. (2003) ‘Occupying a Middle Space: Toward a Metiza Sport Studies’, Sociology of Sport Journal, 20: 1-16.

Jamieson, K.M. (1998) 'Reading Nancy Lopez: Decoding Representations of Race, Class and Sexuality', Sociology of Sport Journal, 15: 343-358.

Jamieson, K.M. and Choi, Y. (2017) 'Lorena "La Reina” Ocha: disindentifying towards a brown solidarity', in A. Ratna and S.F. Samie (Eds.) Race, Gender and Sport: The Politics of Ethnic 'Other' Girls and Women, London: Routledge: 171-188.

Jiwani, N., and Rail, G. (2010) ‘Islam, Hijab and Young Shia Muslim Canadian Women’s 
Discursive Constructions of Physical Activity', Sociology of Sport journal, 27(3): 250-267.

Joseph, J. (2008) “"Going to Brazil”: transnational and corporeal movements of a CanadianBrazilian martial arts community', Global Networks: A Journal of Transnational Affairs, 8(2): 194-213.

Kaplan, C. (1994) 'The Politics of Location as Transnational Feminist Practice' in I. Grewal and C. Kaplan (Eds.) Scattered Hegemonies: Postmodernity and Transnational Feminist Practices, Minneapolis; London: University of Minnesota Press: 137-152.

Kaplan, C., and Grewal, I. (1999) 'Transnational Feminist Cultural Studies: Beyond the Marxism/ Poststructuralism/ Feminism Divides' in C. Kaplan, N. Alarcón and M. Moallem (Eds.) Between Women and Nation: Nationalisms, Transnational Feminisms and the State, Durham, London: Duke University Press: 349-363.

Kedhar, A. (2014) 'Flexibility and Its Bodily Limits: Transnational South Asian Dancers in an Age of Neoliberalism', Congress of Research in Dance, 46(1): 23-41.

Kim, K. (2013) 'Translation with Abusive Fidelity: Methodological Issues with translating media text about Korean LPGA players', Sociology of Sport Journal, 30: 340-358.

Kim, K. (2012) Producing Korean Women Golfers on the LPGA Tour: Representing Gender, Race, Nation and Sport in Transnational Context, unpublished thesis: University of Toronto.

Kivel, B.D., Johnson, C.W. and Scraton, S. (2009) '(Re)Theorizing Leisure, Experience and Race', Journal of Leisure Research, 41(4): 473-493.

Leseth, A.B. (2014) 'Experiences of Moving: A history of women and sport in Tanzania', Sport in Society, 17(3): 479-491.

Lorde, A (2007). Sister Outsider. 2nd ed. Berkeley: Crossing Press. 
Lorde, A. (1997) ‘Age, Race. Class and Sex: Women Redefining Difference’ in A.

McClintock, A. Mufti and E. Shohat (Eds.) Dangerous Liaisons: Gender, Nation and

Postcolonial Perspectives, London; Minneapolis: University of Minnesota Press: 374-280.

Lu, L. (1997) 'Critical Visions: The Representation and Resistance of Asian Women' in S. Shah (Ed.) Dragon Ladies: Asian American Feminists Breathe Fire, Boston: South End: 1728.

Lugones, M. (1990) 'Playfulness, “World”-Travelling, and Loving Perception', in G.

Anzaldúa (Ed.) Haciendo Caras/ Making Face, San Francisco: Aunt Lue: 390-402.

McDonald, M. G. and Shelby, R. (2017) 'Feminism, Intersectionality and the Problem of Whiteness in Leisure and Sport Practices and Scholarship', in L. Mansfield, J. Caudwell, B. Wheaton and B. Watson (Eds.) The Palgrave Handbook of Feminism and Sport, Leisure and Physical Education, London: Palgrave Macmillan: 497-514.

McDonald, M.G. (2009) 'Dialogues on Whiteness, Leisure and (Anti)Racism', Journal of Leisure Research, 41(1): 5-21.

McDonald, M.G. (2000) ‘The Marketing of the Women's National Basketball Association and the Making of Postfemism', International Review for the Sociology of Sport, 35(1): 3547.

McRobbie, A. (2009) The Aftermath of Feminism: Gender, Culture and Social Change, London: Sage Publications.

Mitra, P. (2014) 'The untold stories of female athletes with intersex variations in India' in J. Hargreaves and E.Andersen (Eds.) The Handbook of Sport, Gender and Sexuality, London; New York: Routledge: 384-394.

Mitra, P. and Chawansky, M. (2018) 'Earnest Travellers: Bodies (that) matter in transnational 
feminist research', in T. F. Carter, D. Burdsey and M. Doidge (Eds.) Transforming Sport: Knowledge, Practices and Structures, London: Routledge: 195-206.

Mane, R.L.C. (2012) 'Transmuting Grammars of Whiteness in Third-Wave Feminism: Interrogating Postrace Histories, Abstraction, and the Proliferation of Difference in ThirdWave Texts', Signs, 38(1): 71-98.

Mirza, H.S. (1997) Black British Feminism: A Reader. London: Routledge.

Mohanty, C.T. (2013) 'Transnational Feminist Crossings: On Neo-liberalism and Radical Critique', Signs: Journal of Women in Culture and Society, 38(4): 967-991.

Mohanty, C.T. (2003) Feminism without Borders: Decolonizing Theory, Practicing Solidarity, Durham and London: Duke University Press.

Moraga, C., and Anzaldúa, G. (2015) This Bridge Called My Back: Writings by Radical Women of Color, Fourth Edition: Albany: State University of New York Press.

Mowatt, R.A., French, B.H., and Malebranche, D.A. (2013) 'Black/Female/Body Hypervisibility and Invisibility', Journal of Leisure Research, 45(5): 644-660.

Narayan, U. (1997) Dislocating Cultures: Identities, Traditions and Third World Feminism, New York: Routledge

Nicholls, S., Giles, A.R., and Sethna, C. (2010) 'Perpetuating the "lack of evidence" discourse in sport for development: Privileged voices, unheard stories and subjugated knowledge', International Review for the Sociology of Sport, 46(3): 249-264.

Oza, R. (2016) 'The entanglements of transnational feminism and area studies', Environment and Planning D: Society and Space, 34(5): 836-842.

Palmer, C. (2009) 'Soccer and the Politics of Identity for young Muslim refuge women in 
South Australia', Soccer and Society, 10(1): 27-38.

Palmer, F.R. and Masters, T.M. (2010) 'Māori feminism and sport leadership: Exploring Māori women's experiences', Sport Management Review, 13: 331-344.

Pelak, C.F. (2005) 'Negotiating Gender/Race/Class Constraints in the New South Africa', International Review for the Sociology of Sport, 40(1): 53-70.

Raval, S. (1989) 'Gender, Leisure and Sport: A Case Study of Young People of South Asian Descent', Leisure Studies, 8: 237-240.

Ringrose, J. (2007) 'Successful girls? Complicating post-feminist, neoliberal discourses of educational achievement and gender equality', Gender and Education, 19(4): 471-489.

Ross, J.R. (2009) 'Black Female Athletes as the Ultimate Other: Breaking free from the controlling images', The Moving Towards Justice Series: A Projects of NAGWS' Inclusion and Social Justice Committee, 1(1): 1-22.

Samie, S.F. (2017) 'De/colonising “sporting Muslim women”: post-colonial feminist reflections on the dominant portrayal of sporting Muslim women in academic research, public forums and mediated representations', in A. Ratna and S.F. Samie (Eds.) Race, Gender and Sport: The Politics of Ethnic 'Other' Girls and Women, London: Routledge:

Samie, S.F. (2013) 'Hetero-sexy self/body work and basketball: The invisible sporting women of British Pakistani Muslim heritage', South Asian Popular Culture, 11(3): 257-270.

Samie. S.F. and Toffoletti, K. (forthcoming) 'Postfeminist Paradoxes and Cultural Difference: Unpacking Media Representations of American Muslim Sportswomen Ibtihaj Muhammad and Dalilah Muhammad' in K. Toffoletti et al, New Sporting Femininities: Embodies Politics in Postfeminist Times: Palgrave: Macmillan.

Scraton, S.J. (2001) 'Reconceptualising race, gender and sport: the contribution of black 
feminism' in B. Carrington and I. McDonald (eds.) Race, Sport and British Society, London: Routledge: 170-187.

Shankar, S. (2013) 'Affect and sport in South Asian American Advertising', South Asian Popular Culture, 11(3): 231-242.

Shih, S.M. (2002) "Towards an ethics of transnational encounters, or 'when' does a 'Chinese' woman become a 'feminist'?” Difference, 13(2): 90-126.

Shohat, E. (2002) 'Area Studies, Gender Studies, and the Cartographies of Knowledge', Social Text, 20(3): 67-78.

Smith, Y.R. (1992) 'Women of Color in Society and Sport', Quest, 44: 228-250.

Spencer, N.E. (2004) 'Sister Act VI: Venus and Serena at Indian Wells: "Sincere Fictions" and White Racism', Journal of Sport and Social Issues, 28(2): 115-135.

Spivak, G.C. (1988) ‘Can the Subaltern Speak?’ in C. Nelson and L.Grossberg (Ed.) Marxism and the Interpretation of Culture, Macmillan Education: Basingstoke: 271-313.

Spivak, G.C. (1985) 'Three Women's Text and a Critique of Imperialism', Critical Inquiry, 12(1): 243-261.

Strongman, L. (2014) 'Postcolonialism and international development studies: a dialectic exchange?' Third World Quarterly, 35(8): 1343-1354.

Sykes, H. (2016) The Sexual and Gender Politics of Sport Mega-Events: Roving Colonialism, London; New York: Routledge.

Sykes, H. (2014) 'Un-settling sex: Researcher self-reflexivity, queer theory and settler colonial studies', Qualitative Research in Sport, Exercise and Health, 6(4): 583-589. Thangaraj, S. (2015) Desi Hoop Dreams: Pick-up basketball and the making of Asian 
American Masculinity, New York; London: New York University Press.

Thangaraj, S. (2010) “"Liting it up”: Popular Culture, Indo-Pak Basketball, and South Asian American Institutions', Cosmopolitan Civil Societies, 2(2): 71-93.

Thangaraj, S., Constancio, R. A., and Chin, C. (2016) Asian American Sporting Cultures, New York; London: New York University Press.

Theberge, N. (1987) 'Sport and Women's Empowerment', Women's Studies International Forum, 10(4): 387-393.

Toffoletti, K. and Palmer, C. (2015) 'New approaches for studies of Muslim women and sport', International Review for the Sociology of Sport, DOI: $10.1177 / 1012690215589326$ Van Ingen, C. (2013) “"Seeing what frames our seeing”: Seeking histories on early Black Female Boxers', Journal of Sports History, 40(1): 93-110.

Vertinsky, P. and Captain, G. (1998) 'More Myth than History: American Culture and the Representations of the Black Female's Athletic Ability', Journal of Sport History, 25(3): 532 561.

Watson, B. and Scraton, S.J. (2017) 'Re-Confronting Whiteness: on-going challenges in sport and leisure research', in A. Ratna and S.F. Samie (Eds.) Gender, Race and Sport: The politics of Ethnic 'Other' Girls and Women, London: Routledge: 85-106.

Watson, B. and Scraton, S.J. (2001) 'Confronting Whiteness: Researching the leisure lives of South Asian mothers', Journal of Gender Studies, 10(3): 265-277.

Withycombe, J.L. (2011) 'Intersecting Selves: African American Female Athletes' Experiences of Sport', Sociology of Sport Journal, 28: 478-493. 
Yep, K.S. (2012) 'Peddling Sport: liberal multiculturalism and the racial triangulation of blackness, Chineseness and Native American-ness in Professional Basketball', Ethnic and Racial Studies, 35(6): 971-987.

Yep, K.S. (2010) 'Playing rough and tough: Chinese American Women Basketball Players in the 1930s and 1940s', Frontiers: A Journal of Women's Studies, 31(1): 123-141. 